\title{
PENERAPAN FUNGSI SOSIAL ATAS TANAH DALAM PENETAPAN \\ TANAH TERLANTAR OLEH BADAN PERTANAHAN NASIONAL (STUDI \\ TERHADAP: KEPUTUSAN KEPALA BADAN PERTANAHAN NASIONAL REPUBLIK INDONESIA NO: 14/PTT-HGB/BPN RI/2014)
}

\author{
Agripina \\ (Mahasiswa Program S1 Fakultas Hukum Universitas Tarumanagara) \\ (E-mail: agripina.tanto@yahoo.com)
}

\section{Hanafi Tanawijaya}

(Corresponding Author)

(Dosen Fakultas Hukum Universitas Tarumanagara. Meraih Sarjana Hukum pada Fakultas Hukum Universitas Tarumanagara, Magister Hukum pada Fakultas Hukum Universitas Tarumanagara)

(E-mail: hanafitanawijaya@fh.untar.ac.id)

\begin{abstract}
Land is a gift from God that must be used to fulfill human needs. However there are lands that have been abandoned by the land right holder for years. Abandonment of land has been commonly found in many rural areas in Indonesia. Abandoned land is regulated in Government Regulation Number 11 Year 2010 on Disciplining and Empowerment of Abandoned Land. The land right holder is basically prohibited from abandoning the land. However, in case that the right holder left the land unused, not utilized in accordance with the circumstances or the purpose of granting the rights, it leads to legal consequences such as the abolition of the land rights concerned and the termination of legal relations and affirmed as land directly controlled by the state. According to Article 6 Act No. 5 Of 1960 Concerning Basic Regulations on Agrarian Principles, all rights on land have a social function. The State can allocate the abandoned land for public interest considering land has not only economic values, but also social values.
\end{abstract}

Keywords: Abandoned Land, Legal Consequences, Social Function.

\section{PENDAHULUAN}

\section{A. Latar Belakang}


Indonesia dikaruniai kekayaan alam yang beraneka ragam. Kekayaan alam ini salah satunya berupa area tanah yang begitu luas yang sewajarnya dapat dikelola, dimanfaatkan serta dipelihara seoptimal mungkin sebagai sumber kehidupan serta sebagai sumber penghidupan. Hal ini sesuai dengan apa yang telah diarnanatkan dalam Pasa1 33 Ayat (3) Undang-Undagn Dasar Negara Republik Indonesia Tahun 1945, yang menyebutkan bahwa bumi, air dan kekayaan alarn yang terkandung didalarnnya dikuasai oleh Negara dan dipergunakan untuk sebesar-besarnya kernakmuran rakyat, maka sebagian tanah dari Bangsa Indonesia ini ditujukan untuk menyelenggarakan kepentingan umum. Tanah yang dikaruniakan oleh Tuhan kepada manusia ini selayaknya dipakai untuk tempat tinggal, tempat usaha, dan tempat berbagai kegiatan lain yang terkait dengan kehidupan. ${ }^{1)}$ dengan demikian, jelaslah bahwa tanah mengandung amanat untuk diusahakan dan dimanfaatkan.

Pada hakikatnya terdapat dua tujuan dari pemakaian tanah. Tujuan pemakaian tanah yang pertama adalah untuk diusahakan. Beberapa contohnya adalah untuk perkebunan, pertanian dan sebagainya. Sementara, tujuan pemakaian tanah yang kedua adalah untuk dipakai menjadi tempat membangun. Seperti untuk membangun rumah, gedung, jalan, fasilitas umum dan lain sebagainya. ${ }^{2)}$ Dalam ruang lingkup agraria, tanah mempunyai arti atau dapat diartikan sebagai permukaan burni. Dalam hal ini tanah bukan diatur dalam segala aspeknya tetapi hanya aspek tanah dalam pengertian yuridis saja yaitu hak. ${ }^{3)}$

\footnotetext{
1) Yuwono. "Tanah Terlantar Menyalahi Fungsi Sosial". Jurnal Sosial Humaniora. Volume 2 Nomor 1 Juni 2009, hal. 1.

2) Boedi Harsono, Hukum Agraria Indonesia, Sejarah Pembentukan Undang-Undang Pokok Agraria, Asas dan pelaksanaannya, Cetakan ke-2, (Jakarta: Universitas Tri Sakti, 2015), hal. 285.

3) Urip Santoso, Hukum Agraria dan Hak-Hak atas Tanah, Cetakan ke-5, (Surabaya: Kencana Prenada Media Group, 2009), hal. 10.
} 
Hukum pertanahan di Indonesia diatur dalam Undang-Undang Nomor 5 Tahun 1960 tentang Peraturan Dasar Pokok-Pokok Agraria atau yang juga disebut sebagai UUPA. Terdapat berbagai macam hak atas tanah di Indonesia yang tercantum dalarn Pasa1 16 Ayat (1) UUPA, yang diantaranya adalah Hak Milik (HM), Hak Guna Usaha (HGU), Hak Guna Bangunan (HGB), Hak Pakai, Hak Sewa, Hak Membuka Tanah, Hak Memungut Hasil Hutan, serta Hak-hak yang tidak termasuk dalam hak-hak tersebut diatas yang akan ditetapkan dengan undang-undagn serta hak-hak yang sifatnya sementara. Dalam Pasa1 53 UUPA, diatur mengenai hak-hak yang bersifat sernentara yaitu antara lain hak gadai, hak usaha bagi hasil, hak menurnpang dan hak sewa tanah pertanian.

Hak atas tanah sendiri memiliki arti sebagai hak atas sebagian tertentu perrnukaan bumi, yang berbatas, berdiimensi dua dengan ukuran panjang dan lebar. Selain itu, hak atas tanah juga dapat diartikan sebagai hak yang mernberi wewenang kepada pemegang haknya untuk mempergunakan atau mengarnbil manfaat dari tanah yang dihakinya. Dalam hal ini, kata "mempergunakan" mempunyai arti bahwa hak atas tanah itu dipergunakan untuk kepentingan mendirikan bangunan, sedangkan kata "mengarnbil manfaat" mempunyai arti hak atas tanah itu dipergunakan untuk kepentingan bukan mendirikan bangunan, misalnya pertanian, perkebunan, perikanan, dan sebagainya. ${ }^{4}$

Hak-hak atas tanah ini dikelompokan menjadi hak-hak atas tanah primer dan sekunder. Dalam hal ini yang dimaksud dengan hak-hak atas tanah primer adalah hak-hak atas tanah yang dapat dimiliki atau dikuasai secara langsung oleh seseorang atupun badan hukurn yang mernpunyai waktu lama dan dapat dipindah tangankan kepada orang lain atau ahli warisnya. Beberapa

4) Ibid., hal. 11. 
hak yang termasuk dalam hak-hak atas tanah prirner adalah Hak Milik (HM), Hak Guna Usaha (HGU), Hak Guna Bangunan (HGB), Hak Pakai. Selain itu terdapat pula hak atas tanah sekunder yaitu hak-hak atas tanah yang bersifat sernentara. Kemudian yang dimaksud dengan sementara adalah dikarenakan hak-hak tersebut hanya dapat dinikmati dalam jangka waktu yang terbatas. Hak-hak ini juga dikatakan sekunder karena hak-hak itu dirniliki oleh orang lain. Beberapa hak yang merupakan hak-hak atas tanah sekunder adalah hak yang diatur dalam Pasa1 53 UUPA. ${ }^{5}$

Jika hak atas tanah sudah diperoleh tapi tidak diusahakan maka suatu bidang tanah tersebut dapat menjadi objek tanah terlantar. Pada dasarnya jika membiarkan suatu bidang tanah dalam keadaan tidak dimanfaatkan, maka hal ini telah menyalahi amanat yang terkandung dari tanah tersebut. Dengan ditemukan tanah-tanah dalam areal yang luas yang tidak dimanfaatkan sesuai rencana peruntukannya, tentunya hal ini akan memberi konsekuensi berupa tindakan dari Negara yaitu dilakukannya penertiban tanah yang diterlantarkan tersebut dan menjadikan tanahnya sebagai tanah Negara yang dapat diberikan kepada pihak lain yang memerlukannya. ${ }^{6)}$

Penertiban tanah terlantar juga erat berkaitan dengan dinamika pembangunan dan semakin banyaknya kebutuhan manusia yang mengakibatkan permintaan akan lahan kian meningkat. Sedangkan dilain pihak, persediaan akan tanah sangat terbatas. ${ }^{7)}$ Kelangkaan tanah juga berkaitan erat dengan pertambahan jumlah dan kepadatan penduduk. Kepadatan penduduk merupakan banyaknya penduduk per kilometer persegi. Semakin banyaknya penduduk, maka kebutuhan akan tanah juga

${ }^{5)}$ Supriadi. Hukum Agraria, Cetakan ke-4,(Jakarta: Sinar Grafika, 2010), hal.63.

6) Maria. S. W. Soemardjono, Kebijakan Pertanahan antara Regulasi dan Implementasi, Cetakan ke-3. (Jakarta: Kompas, 2005), hal. 180.

${ }^{7)}$ I Wayan Suandra, Hukum Pertanahan Indonesia, (Jakarta: Rineka Cipta,1991), hal. 7. 
semakin meningkat. Hal ini dapat menyebabkan tanah menjadi barang yang langka sehingga dapat menyebabkan nilai sebidang tanah akan terus meniingkat. ${ }^{8)}$

Pada hakikatnya tindakan penelantaran tanah oleh pemegang hak atas tanah dapat menimbulkan efek negatif yang dapat merugikan banyak pihak. Hal ini diantaranya adalah munculnya kesenjangan sosial dan ekonomi, menurunnya kualitas lingkungan seperti tanahnya menjadi kurang kesuburannya, dan lain sebagainya. Guna mencegah efek-efek negatif dari adanya penelantaran tanah tersebut, maka penelantaran tanah harus diantsipasi sedini mungkin. Upaya yang dilakukan pemerintah dalam mengurangi penelantaran tanah adalah dengan melakukan penertiban dan pendayagunaan tanah terlantar sesuai dengan PP No. 11/ 2010. ${ }^{9)}$

Di Indonesia, semua hak atas tanah mempunyai fungsi sosial. Hal ini selaras dengan apa yang tercantum dalam Pasa1 6 UUPA. Pasa1 6 UUPA ini memuat suatu pernyataan penting yang merumuskan sifat kebersamaan dan kernasyarakatan hak-hak atas tanah rnenurut konsepi Hukum Tanah Nasional. Dalam hal ini tanah mempunyai fungsi sosial yang sama artinya degan berfungsi sosial, bukan hak-hak atas tanah adalah fungsi sosial. Pernyataan hak-hak atas tanah adalah fungsi sosial merupakan pengingkaran dari hak perorangan. Dengan demikian Pasal 6 UUPA mengakui adanya hak perseorangan atas tanah. ${ }^{10)}$

Fungsi sosial dalam konsepsi Hukum Tanah Nasional menunjukkan bahwa manusia merupakan pribadi sekaligus makhluk sosial yang

8) Anton Tan, The Real Secret of Succesful Investor and Developer, (Jakarta: PT. Elex Mediia Komputindo, 2014), hal. 37.

9) Evert M. N. Poluan."Kewenangan Pemerintah Daerah Dalam Penanganan Tanah Terlantar di Kabupaten Minahasa". Lex Administratu, Volume 3 Nomor 5 Juli 2015, hal. 1.

10) Boedi Harsono, Op. Cit., hal. 302. 
mengusahakan terwujudnya keselarasan antara kepentingan pribadi dengan kepetingan bersama. ${ }^{11)}$

Dalam Keputusan Kepala Badan Pertanahan Nasional Republik Indonesia No: 14 /PTT- HGB/ BPN RI/ 2014, PT Sinar Waluyo selaku pemegang HGB Nomor 01249/ Tondo, hak atas tanahnya dihapus karena dinyatakan tanah terlantar. Tetapi PT Sinar Waluyo membantah bahwa tanah tersebut merupakan tanah yang tidak diusahakan.

Pada dasarnya, dalam menetapkan penetapan tanah terlantar, BPN wajib mengidentifikasi tanah terindikasi terlantar sesuai dengan Peraturan Pemerintah No. 11/ 2010 Tentang Penertiban dan Pendayagunaan Tanah Terlantar. Dari hasil identifikasi tanah terlantar, Kepala Kantor Wilayah memberi peringatan tertulis sebanyak tiga kali sampai pada akhirnya ketika setiap peringatan tidak diindahkan, tanah yang bersangkutan dinyatakan sebagai tanah terlantar oleh BPN RI atas usul Kepala Kantor Wilayah dan menjadi tanah yang dikuasai langsung oleh Negara.

\section{B. Perumusan Masalah}

Berdasarkan latar belakang masalah tersebut di atas, maka dapat dirurnuskan permasalahan sebagai berikut yaitu: Bagaimana Penerapan Fungsi Sosial Tanah dalam Perspektif Penetapan Tanah Terlantar Melalui Keputusan Kepala Badan Pertanahan Nasional Republik Indonesia No: 14/ PTT-HGB/ BPN RI/ 2014 ?

\section{Metode Penelitian}

1. Jenis penelitian

11) Shanan, Hukum Agraria Indonesia. (Jakarta: Setara Press, 2016), hal. 46. 
Penelitian ini menggunakan rnetode penelitian normatif. Metode penelitian hukum normatif merupakan suatu proses untuk rnenemukan suatu aturan hukum, prinsip -prinsip hukurn, maupun doktrin-doktrin hukurn guna menjawab isu hukum yang dihadapi. ${ }^{12)}$

2. Jenis dan Teknik Pengumpulan Bahan Hukum

Berkenaan dengan rnetode penelitian hukurn normatif tersebut, teknik pengurnpulan bahan hukurn yang digunakan adalah studi dokumen atau studi kepustakaan.

Sumber penelitian hukum dari metode normatif ini terbagi menjadi tiga jenis yaitu bahan hukum prirner, bahan hukum sekunder dan bahan non-hukum. Bahan hukum prirner yaitu berupa Undagn-Undang, peraturan lain yang berlaku, serta putusan pengadilan. Bahan hukum sekunder terdiri dari buku hukum, jurnal hukurn, serta bahan dari internet yang terkait dengan fungsi sosial atas tanah dalam penetapan tanah terlantar serta bahan non-hukum yaitu berupa buku, jurnal, penelitian non-hukum yang dapat menunjang penelitian ini.

\section{Pendekatan Penelitian}

Dalam metode penelitian normatif menurut Peter Mahrnud Marzuki terdapat beberapa pendekatan. Hal ini dimaksudkan agar peneliti mendapatkan informasi dari bebagai aspek mengenai isu yang akan dijawab. Terdapat lima pendekatan yang diantaranya adalah pendekatan undang-undang, pendekatan kasus, pendekatan historis, pendekatan

12) Peter Mahrnud Marzuki, Penelitian Hukum (Jakarta: Kencana Prenada Media Group, 2016), hal 59. 
komparatif dan pendekatan konseptual. Pada penelitian ini pendekatan digunakan adalah undang-undagn dan pendekatan kasus. ${ }^{13)}$

4. Sifat Penelitian

Sifat dari penelitian ini adalah preskriptif. Dimana dikumpulkanlah saran serta pendapat dari ahli-ahli hukum mengenai bagaimana tata cara penetapan tanah terlantar sesuai dengan peraturan yang berlaku, sehingga dari pendapat dan saran ahli hukum tersebut dapat ditemukan bagaimana penerapan fungsi sosial atas tanah dalam penetapan tanah terlantar oleh Badan Pertanahan Nasional.

5. Teknik Analisis Data

Menurut Peter Mahrnud Marzuki, terdapat dua metode yang lazim digunakan dalam pemecahan isu hukum. Kedua metode ini adalah metode deduktif dan metode induktif. Penelitian ini menggunakan teknik analisis data/bahan hukum dengan metode deduktif yaitu menjelaskan suatu hal yang bersifat umum kemudian menarik kesimpulan yang lebih khusus. Hal yang bersifat umum tersebut merupakan peraturan perundang-undangan lalu ditarik kesimpulan mengenai hal bersifat khususnya yaitu bagaimana penerapan fungsi sosial atas tanah dalam penetapan tanah terlantar oleh Badan Pertanahan Nasional.

\section{PEMBAHASAN}

Penerapan Fungsi Sosial Tanah dalam Perspektif Penetapan Tanah Terlantar Melalui Keputusan Kepala Badan Pertanahan Nasional Republik Indonesia No: 14/PTT-HGB/BPN RI/2014.

13 ) Ibid., hal. 181. 
Di Indonesia, hukum pertanahan diatur dalam Undang-Undang No. 5 Tahun 1960 tentang Peraturan Dasar Pokok-Pokok Agraria atau yang bisa disebut sebagai UUPA. Kata agraria merupakan kata yang berasal dari bahasa latin yaitu agrarius yang berarti perladangan, pertanian, persawahan, dsb. Pengertian agraria juga dapat berarti sebagai segala sesuatu yang berpautan dengan masalah tanah, baik yang ada di dala tanah ataupun yang terdapat diatasnya. ${ }^{14)}$ Tanah dalam ruang lingkup agraria mempunyai arti sebagai permukaan bumi. Dalam hal ini tanah bukan diatur dalam segala aspeknya tetapi hanya aspek tanah dalam pengertian yuridiis saja yaitu hak. ${ }^{15)}$

Menurut Pasa1 2 PP No. 20/ 2015 tentang Badan Pertanahan Nasional, instansi pemerintah yang bertugas dalam melaksanakan tugas pemerintahan dibidang pertanahan adalah Badan Pertanahan Nasional atau yang biasa disebut dengan BPN.

Negara dapat memberikan berbagai macam hak atas tanah kepada perseorangan baik sendiri maupun bersama-sama dengan orang lain serta badan-badan hukum sesuai keperluannya. Setiap warga negara Indonesia juga diberikan kesempatan untuk menguasai atau menghaki bagian dari tanah bersama Bangsa Indonesia untuk memenuhi kebutuhan priibadinya masing-masing. ${ }^{16)} \mathrm{Hal}$ ini berkaitan dengan hak menguasai Negara. Pemberian hak atas tanah bukan hanya berisikan wewenang semata, tetapi juga diikuti oleh kewajiban-kewajiban yang wajib dipenuhi oleh pemegang hak atas tanah.

Negara memberikan hak atas tanah untuk diusahakan, idipergunakan, atau dimanfaatkan sesuai dengan keadaannya atau sifat dan tujuan pemberian hak atau dasar penguasannya. Hak-hak atas tanah di Indonesia diatur dalam Pasa1 16 UUPA, hak atas tanah yang dapat diperoleh dibagi menjadi delapan hak yaitu:

14) Soesilo Prayogo, Kamus Hukum Internasional \& Indonesia, Cetakan ke-1. (Jakarta: Wipress, 2007), hal. 25.

${ }^{15)}$ Urip Santo, Op. Cit., hal. 10.

16) Boedi Harsono, Op. Cit., hal. 297. 
"Hak-hak atas tanah yang dimaksud Pasa1 4 ayat (1) tersebut ialah:
a. Hak Milik
b. Hak Guna Usaha
c. Hak Guna Bangunan
d. Hak Pakai
e. Hak Sewa
f. Hak Membuka Tanah
g. Hak Memungut Hassil Hutan
h. Hak-hak yang tdak termasuk dalam hak-hak tersebut diatas yang akan ditetapkan dengan undagn-undang serta hak-hak yang sifatnya sementara."

Hak atas tanah selanjutnya juga diatur dalam Pasa1 53 UUPA yang menyebutkan bahwa: Hak-hak yang sifatnya sementara sebagamana yang dimaksud dalam Pasa1 16 Ayat (.1) huruf h adalah, hak gadai, hak usaha bagi hasil, hak menumpang dan hak sewa tanah pertanian.

Hak-hak atas tanah yang telah diperoleh ini dapat hapus haknya karena beberapa hal yang salah satu diantaranya adalah karena ditelantarkan. Hal ini dapat terjadi apabila pemegang hak atas tanah tidak mengusahakan, mempergunakan, atau memanfaatkan tanahnya sesuai dengan keadaannya atau sifatt dan tujuan pemberian hak atau dasar penguasaannya sehingga menimbulkan konsekuensi berupa tindakan dari Negara yaitu dilakukannya penertiban tanah yang diterlantarkan tersebut dan menjadikan tanahnya sebagai tanah Negara yang dapat diberikan kepada pihak lain yang memerlukannya. ${ }^{17)}$ Menurut Pasa1 1 angka 7 Perka BPN No. 4/ 2010 yang dimaksud dengan penertiban tanah adalah sebagai proses penataan kembali tanah terlantar agar dapat dimanfatkan seoptimal mungkin untuk kepentingan masyarakat dan negara.

Sementara, pengertian tanah terlantar menurut Pasa1 1 angka 6 Perka BPN RI No. 4/ 2010 tentang Tata Cara Penertiban Tanah Terlantar dicantumkan bahwa:

17) Maria.S.W. Soemardjono, Kebijakan Pertanahan antara Regulasi dan Implementasi, Cetakan ke-3. (Jakarta: Kompas, 2005), hal. 180. 
"Tanah terlantar adalah tanah yang sudah diberikan hak oleh negara berupa Hak Milik, Hak Guna Usaha, Hak Guna Bangunan, Hak Pakai, dan Hak Pengelolaan, atau dasar penguasaan atas tanah yang tidak diusahakan, tidak dipergunakan, atau tidak dimanfaatkan sesuai dengan keadaannya atau sifat dan tujuan pemberian hak atau dasar penguasaannya."

PT Sinar Waluyo merupakan perusahaan pengembang perumahan yang kemudian membeli tanah HGB (HGB) Nomor 09/Tondo seluas 848.320 Ha yang terletak di Kelurahan Tondo, Kecamatan Palu Timur, Kota Palu, Sulawesi Tengah. Tanah HGB 09/Tondo ini tertanggal 25 Agustus 1989 dan akan berakhir haknya tanggal 25 Agustus 2019. Pada tahun 2010 PT Sinar Waluyo memecah HGB Nomor 09/Tondo menjadi beberapa bagian yang salah satunya adalah HGB 01249/Tondo seluas 2,863 Ha. PT Sinar Waluyo kemudian mengusahakan tanahnya dengan memperoleh izin lokasi No. SK 188.44/3309/ Agraria pada tahun 2008.

Dalam hal ini PT Sinar Waluyo hak atas tanahnya dihapus karena tanah HGU 01249/ Tondo ditetapkan sebagai tanah terlantar dengan diterbitkannya Keputusan Kepala Badan Pertanahan Nasional Republik Indonesia No: 14 /PTT-HGB/ BPN RI/ 2014. Kemudian PT Sinar Waluyo mengugat penetapan tanah terlantar atas tanah HGB 01249/ Tondo di Pengadilan Tata Usaha Negara Jakarta. Lalu terbitlah Putusan PTUN No: 275/G/2014/PTUN-JKT yang membatalkan Keputusan Kepala BPN RI No: 14/PTT-HGB/ BPN RI/ 2014 yang kemudian menyebabkan tanah HGB 01249/ Tondo kembali diperoleh PT Sinar Waluyo.

PT Sinar Waluyo pertama kali mengusahakan tanahnya dengan memperoleh izin lokasi dengan No. SK 188.44/3309/Agraria pada tahun 2008 yang ditujukan untuk dijadikan perumahan. Dalam hal ini PT Sinar Waluyo selaku pemegang hak atas tanah telah tidak mengusahakan, mempergunakan, atau memanfaatkan tanahnya sesuai dengan keadaannya atau sifat dan tujuan pemberian hak atau dasar penguasaannya selama lebih dari 19 tahun. 
Dalam kurun waktu lebih dari 19 tahun penelantaran tanah HGB 01249/ Tondo, BPN harusnya melakukan tindakan penertiban tanah terlantar pada tanah tersebut sehingga HGB 01249/ Tondo dapat digunakan secara lebih optimal. Berdasarkan Pasa1 8 Ayat (1) huruf c Keputusan Kepala BPN Nomor 24 Tahun 2002 tentang Ketentuan Pelaksanaan PP No. 36/ 1998 jangka waktu minimal untuk dilakukan identifikasi Hak Guna Usaha adalah 3 tahun. Hal ini sejalan dengan Pasa1 6 Ayat (1) huruf a dan b PP No. 11/ 2010 yang menyatatakan bahwa identfikasi dan penelitian tanah terhitung mulai 3 tahun sejak diterbitkan Hak Milik, Hak Guna Usaha, Hak Guna Bangunan, Hak Pakai atau sejak berakhirnya izin/ keputusan/ surat dasar penguasaan atas tanah dari pejabat yang berwenang.

Pada tahun 2008 PT Sinar Waluyo memperoleh izin lokasi dengan No. SK 188.44/3309/, kemudian PT Sinar Waluyo mengajukan permohonan izin mendirikan bangunan untuk tanah HGB Nomor 01249/ Tondo yang kemudian ditolak Pemerintah Kota Palu yang dibuktikan dengan Surat Penolakan Pemerintah Kota Palu No. 548 /194/ 18/ DPRP/ 2010 dan No. 650 /78 /19/ DPRP/ 2011.

Pemerintah Kota Palu menolak permohonan izin mendirikan bangunan yang dimohonkan oleh PT Sinar Waluyo tersebut karena terdapat Revisi Rencana Tata Ruang Wilayah Kota Palu dimana tanah HGB 01249/ Tondo milik PT Sinar Waluyo tersebut termasuk dalam wilayah yang akan dibangun perkantoran milik Pemerintah Kota Palu. Dengan demikian, dasar penguasaan atas tanah yang telah diperoleh PT Sinar Waluyo yaitu untuk membangun perumahan pada tanah HGB 01249/ Tondo sudah tidak sesuai lagi dengan Rencana Tata Ruang Wilayah Kota Palu.

Hal ini juga yang mendasari pertimbangan Hakim bahwa dalam proses penyiapan data, evaluasi dan peneltian serta peringatan tanah terindikasi terlantar harus dilakukan dengan berhati-hati, cermat dan dengan cara yang sistematis sesuai dengan PP No.11/ 2010, sehingga dalam penerbitan keputusan objek sengketa tersebut, berdasarkan Pasa1 3 huruf a PP No.11/ 2010 yang menyebutkan: "Tidak 
termasuk objek penetapan tanah terlantar: Tanah Hak Milik atau Hak Guna Bangunan atas nama perseorangan yang secara tidak sengaja tidak dipergunakan, tidak diusahakan, tidak dimanfaatkan sesuai dengan keadaan atau sifat dan tujuan pemberian hak." Maka secara substansi objek sengketa yaitu Keputusan Kepala Badan Pertanahan Nasional Republik Indonesia No: 14 /PTT-HGB/BPN RI/ 2014 telah bertentangan dengan PP No. 11/ 2010 karena tanah HGB 01249/ Tondo tidak dilanjutkan pemanfaatannya bukan merupakan kesengajaan dari pihak penggugat. Dengan demikian maka HGB 01249/ Tondo tidak termasuk objek penetapan tanah terlantar.

Menurut penulis, Kepala Kantor BPN Wilayah Sulawesi Tengah telah melakukan penertiban tanah terlantar sesuai dengan PP No. 11/ 2010 yang salah satunya adalah dengan membentuk Panitia $\mathrm{C}$ yang bertugas melakukan penelusuran, identifikasi dan penelitian terhadap tanah terindikasi terlantar sesuai dengan yang tercantum dalam Pasa1 9 Perka BPN 4/ 2010 dengan susunan anggota yaitu:

1. Kepala Kantor Wilayah Badan Pertanahan Nasional Provinsi Sulawesi Tengah selaku Ketua;

2. Kepala Bidang Pengendalian Pertanahan dan Pemberdayaan Masyarakat sebagai Sekretaris merangkap anggota;

3. Sekretaris Kota Palu selaku anggota;

4. Kepala Bidang Tata Ruang dan Bina Kontruksi Dinas PU Daerah Provinsi Sulawesi Tengah selaku anggota;

5. Kepala Kantor Pertanahan Kota Palu selaku anggota;

Panitia C selaku panitia yang bertugas meneliti dan mengidentifkasi tanah terindikasi terlantar wajib melakukan penelitian sesuai dengan yang apa tercantum dalam Pasa1 7 Ayat (1) PP No.11/ 2010 yang berbunyi: 
"Kegiatan identifkasi dan penelitian sebagaimana dimaksud dalam Pasa1 6 meliputi:

a. melakukan verifkasi data fisik dan data yuridis;

b. mengecek buku tanah dan/ atau warkah dan dokumen lainnya untuk mengetahui keberadaan pembebanan, termasuki data, rencana, dan tahapan penggunaan dan pemanfaatan tanah pada saat pengajuan hak;

c. meminta keterangan dari Pemegang Hak dan pihak lain yang terkait, dan Pemegang Hak dan pihak lain yang terkait tersebut harus memberi keterangan atau menyampaikan data yang diperlukan;

d. melaksanakan pemeriksaan fisik;

e. melaksanakan ploting letak penggunaan dan pemanfaatan tanah pada peta pertanahan;

f. membuat analisis penyebab terjadinya tanah terlantar;

g. menyusun laporan hasil identifkasi dan penelitian;

h. melaksanakan sidang Panitia; dan

i. membuat Berita Acara."

Pertimbangan Hakim yang selanjutnya adalah bahwa Penggugat telah melakukan permohonan izin mendirikan bangunan yang termasuk dalam tindakan konkrit. Hal ini sesuai dengan yang tercantum dalam Pasa1 15 Ayat (2) huruf c Perka BPN RI No. 4/ 2010, yang berbunyi:

"Tindakan konkrit yang harus dilakukan oleh pemegang hak supaya tidak dijadikan objek tanah terlantar adalah melakukan pengajuan permohonan hak untuk penguasaan dan pengajuan ijin atau keputusan atau surat dari pejabat yang berwenang untuk pemanfaatannya."

Dalam hal ini PT Sinar Waluyo tidak ada usaha melakukan diskusi atau menggugat instansi terkait yaitu Pemerintah Kota Palu untuk mencari jalan keluar mengenai kelanjutan pemanfaatan tanah HGB 01249/Tondo terkait ditolaknya permohonan izin mendirikan bagunan. Bukan malah membiarkan terjadinya penelantaran tanah. Tetapi dalam hal ini, Panitia $\mathrm{C}$ tetap wajib melakukan penelitian dan evaluasi sesuai dengan PP No. 11/2010 dengan melakukan pemanggilan pada 
para pihak untuk meminta keterangan mengenai pemanfaatan tanah HGB 01249/Tondo walau dalam hal ini alasan PT Sinar Waluyo menelantarkan tanahnya karena tidak terbitnya izin mendirikan bangunan karena ada revisi rencana tata ruang tidak dapat dibenarkan. Kantor Wilayah BPN Provinsi Sulawesi Tengah juga wajib memberi peringatan tertulis agar PT Sinar Waluyo menggunakan dan memanfaatkan tanahnya sesuai dengan keadaan, sifat dan peruntukkannya secara cermat, jelas dan terperinci. Sehingga tidak ada kekeliruan antara tanah HGB 09 /Tondo dengan pecahannya yaitu tanah HGB 01249 /Tondo.

Dalam praktik dilapangan sering ditemukan adanya tanah yang tidak dapat dimanfaatkan, diusahakan dan digunakan karena rencana tata ruang wilayahnya sudah berbeda. Dalam hal ini BPN hanya merupakan eksekutor atau pelaksana dalam kegiatan pertiban tanah terlantar yang berpedoman pada PP No. 11/ 2010, sehingga jika BPN menemukan tanah yang tidak diusahakan, dipergunakan, atau dimanfaatkan tanahnya sesuai dengan keadaannya atau sifat dan tujuan pemberian hak atau dasar penguasaannya setelah 3 tahun sejak diterbitkannya sertifikat hak atas tanah, maka BPN akan melakukan tahap-tahap indetifkasi tanah telantar. Dengan demikian pemegang hak atas tanah wajib untuk mencari jalan keluar bersama instansi terkait mengenai kelanjutan pengusahaan, pengunaan, dan pemanfaatan tanah tersebut. Bukan malah membiarkan terjadinya penelantaran tanah.

Penelantaran tanah terbagi dalam dua jenis yaitu penelantaran secara fisik dan penelantaran secara yuridis. Dalam penelantaran tanah secara fisik, tanah yang ditelantarkan dapat terlihat tidak terurus, ditumbuhi rumput liar, dan hal-hal lain yang secara fisik tampak bahwa tidak ada kegiatan diatas tanah tersebut. Hal ini berarti bahwa tanah tersebut tidak digunakan, diusahakan maupun dimanfaatkan sesuai keadaan, sifat dan dasar penguasaannya. Sementara, untuk menyatakan bahwa suatu bidang tanah terlantar secara yuridis, maka harus diadakan inventarisasi dan 
pencarian data mengenai tanah tersebut sehingga sampai pada ditetapkannya tanah tersebut menjadi tanah terlantar oleh BPN RI.

Terdapat dua jenis pemanfaatan tanah yaitu pemanfaatan tanah secara fisik dan pemanfaatan tanah secara yuridis. Dalam segi fisik, pemegang hak atas tanah dapat mengusahakan tanahnya dengan beberapa cara seperti membangun bangunan, berkegiatan, tinggal diatas tanah tersebut dan sebagainya. Sementara, dilihat dari segi yuridis, pemegang hak atas tanah kiranya dapat mengajukan permohonan hak untuk penguasaan dan pengajuan ijin atau keputusan atau surat dari pejabat yang berwenang untuk pemanfaatannya. Sehingga menurut penulis, HGB 01249/ Tondo tidak dimanfaatkan secara fisik karena diatas tanah tersebut tidak dibangun bangunan perumahan sesuai tujuan pemberian. Penulis juga berpendapat bahwa HGB 01249/Tondo tidak dimanfaatkan secara yuridis karena permohonan izin mendirikan bangunannya ditolak oleh Pemerintah Kota Palu sehingga tanah HGB 01249/ Tondo tidak mempunyai ijin/ keputusan/ surat dari pejabat yang berwenang untuk kelanjutan pemanfaatannya. ${ }^{18)}$ Sehingga HGB 01249/ Tondo merupakan tanah yang terlantar secara fisik karena tidak diusahakan sesuai tujuan pemberian haknya yaitu untuk pengembang perumahan. Penulis juga berpendapat bahwa HGB 01249/ Tondo terlantar secara yuridis karena tidak diterbitkannya ijin atau keputusan atau surat dari pejabat yang berwenang untuk pemanfaatannya.

Pemegang hak atas tanah juga tidak menunjukkan usaha dalam memanfaatkan tanahnya dalam tenggang waktu tiga kali peringatan. Kantor BPN Wilayah Sulawesi Tengah memberikan peringatan dengan surat tertulis, yaitu Peringatan I No: 753/ 72/IX/ 2011 tanggal 14 September 2011, Peringatan II No: 984 /72/XI/ 2011 tanggal

18) Peneliti, Wawancara, dengan Sumarto, Kepala Sub. Direktorat Penertiban dan Penetapan Tanah Terlantar, (Jakarta: Direktorat Penertiban dan Pendayagunaan Tanah Terlantar, Kementrian Agraria dan Tata Ruang dan Badan Pertanahan Nasional Republik Indonesia, Jl. Sisingamangaraja No.2, RT.2/RW.1, Selong, Kec. Kby. Baru, Kota Jakarta Selatan, Daerah Khusus Ibukota Jakarta, 21 Mei 2019). 
28 November 2011, Peringatan III No: 1087/ 72/XII/ 2011 Tanggal 28 Desember 2011. Setiap peringatan tersebut berjarak satu bulan. Peringatan pertama yang tenggang waktunya lebih dari yang seharusnya yaitu satu bulan seyogianya menjadi keuntungan bagi penggugat karena mendapat lebih banyak waktu untuk mengusahakan tanahnya. Kantor BPN Wilayah Sulawesi Tengah juga melakukan pemantauan dan evaluasi pada tanah HGB No. 01249/ Tondo dan sampai pada akhir peringatan III, PT Sinar Waluyo masih menelantarkan Hak Guna Bangunan Tersebut. Dalam memberi peringatan ini Kantor BPN Wilayah Sulawesi Tengah tidak memberikan peringatan yang jelas pemisahannya antara tanah HGB 09/Tondo dengan tanah HGB 01249/Tondo. hal ini tentu menimbulkan kerancuan karena pada dasarnya tanah HGB 01249/Tondo sudah pecah dari tanah HGB 09/Tondo.

Dalam hal penelantaran tanah, tenggat waktu yang diberikan kepada pemegang hak dalam mengusahakan tanahnya setelah adanya peringatan sangat terbatas yaitu hanya satu bulan, sementara untuk mengusahakan tanah atau memohon permohonan izin menggunakan tanah memerlukan waktu yang tidak sebentar sehingga seringkali pemegang hak atas tanah sulit mengusahakan tanahnya dalam tenggat waktu yang sedikit tersebut.

Dengan demikian, menurut penulis pertimbangan hukum Majelis Hakim diatas belum tepat karena telah terbukti sebagaimana telah dijelaskan diatas bahwa penggugat telah menelantarkan tanahnya selama lebih dari 19 tahun.

Pengaturan mengenai pertanahan dalam Undang-Undang Pokok Agraria memberikan perhatian yang sama dan seimbang antara kepentingan pribadi dan kepentingan bersama. Hal ini didasari karena kepentingan pribadi dam kepentingan bersama haruslah selaras serta saling mengmbangi satu sama lain sehingga tercapailah tujuan pokok yaitu kemakmuran, keadilan, serta kebahagiaan bagi seluruh rakyat Indonesia. 
Dalam UUPA terkandung berbagai macam asas yang merupakan jiwa dan dasar dari pelaksanaan UUPA. Salah satu dari asas-asas tersebut merupakan asas semua hak atas tanah mempunyai fungsi sosial. Asas ini tercantum dalam Pasal 6 UUPA. Pada dasarnya, terdapat 2 makna yang terkandung dalam asas semua hak atas tanah mempunyai fungsi sosial. Makna tersebut terdiri dari: ${ }^{19)}$

1. Pemegang hak atas tanah berkewajiban utuk mengusahakan, mempergunakan, atau memanfaatkan tanahnya sesuai dengan keadaannya atau sifat dan tujuan pemberian hak atau dasar penguasaannya.

2. Jika dalam mempergunakan, mengusahakan atau memanfaatkan suatu bidang tanah terdapat pertentangan antara kepentingan perseorangan dan kepentingan umum, maka kepentingan umum yang didahulukan.

Dengan demikian, tanah yang dihaki oleh masing-masing pemegang hak atas tanah bukan hanya mempunyai fungsi bagi pemegang haknya saja tetapi juga bagi Bangsa Indonesia. Untuk itu diperlukan perencanaan peruntukkan dan penggunaan tanah. Dengan menggunakan tanah sesuai dengan rencana yang telah ditetapkan pemerintah maka terpenuhilah fungsi sosialnya. Pemegang hak atas tanah wajib memelihara tanah secara baik dan bijak maka pemegang hak atas tanah tidak dibenarkan dalam menggunakan atau tidak menggunakan tanahnya semata-mata hanya untuk kepentingan pribadinya saja, karena pada dasarnya dalam menggunakan tanah, pemegang hak atas tanah harus juga memperhatikan kepentingan umum. Menurut Boedi Harsono, fungsi sosial dalam konsepsi Hukum Tanah Nasional terkait dengan manusia yang merupakan pribadi sekaligus makhluk sosial sehingga adanya fungsi sosial atas tanah merupakan usaha untuk

19) Peneliti, Wawancara, dengan Hasni, Dosen Fakultas Hukum Universitas Tarumanagara, (Jakarta: Universitas Trisakti, Jl. Kyai Tapa No.1, RT.6/RW.16, Tomang, Kec. Grogol petamburan, Kota Jakarta Barat, Daerah Khusus Ibukota Jakarta, 9 Mei 2019). 
mewujudkan keseimbangan, keserasian serta keselarasan antara kepentingan pribadi dan kepentingan bersama. ${ }^{20)}$

Dalam hal ini, PT Sinar Waluyo sebagai pemegang hak atas tanah tidak memenuhi kewajibannya dengan tidak menggunakan, mengusahakan dan memanfaatkan tanah sesuai hak dan tujuan pemberiannya yaitu untuk pengembangan perumahan. Selain itu, tujuan dari fungsi sosial atas tanah tersebut tidak tercapai karena tanah tersebut tidak dikelola secara optimal. Adanya revisi Rencana Tata Ruang Wilayah suatu kota, tidaklah tepat untuk dijadikan alasan menelantarkan suatu bidang tanah karena pada dasarnya jika suatu izin yang telah diperoleh tidak lagi sesuai dengan Rencana Tata Ruang. Wilayah suatu kota, maka hak atas tanah tersebut dapat ditolak untuk permohonan perpanjangan jangka watunya.

Tentunya hal ini berakibat pemegang hak atas tanah hanya memilki kemungkinan kecil untuk memanfaatkan, mengusahakan, atau menggunakan tanahnya sesuai dengan keadaan, sifat dan peruntukannya karena Rencana Tata Ruang Wilayah Kota Palu sudah berubah. ${ }^{21)}$ Hal ini selaras dengan apa yang tercantum dalam Pasa1 30 Ayat (l) Peraturan Pemerintah Nomor 40 Tahun 1996 tentang Hak Guna Usaha, Hak Guna Bangunan dan Hak Pakai yang berbunyi:

"Hak Guna Bangunan atas tanah Negara sebagaimana dimaksud dalam Pasal 22, atas permohonan pemegang hak dapat diperpanjang atau diperbaharui, jika memenuhi syarat :

a. tanahnya masih dipergunakan dengan baik sesuai dengan keadaan, sfat dan tujuan pemberian hak tersebut;

b. syarat-syarat pemberian hak tersebut dipenuhi dengan baik oleh pemegang hak;

c. pemegang hak masih memenuhi syarat sebagai pemegang hak sebagai-mana dimaksud dalam Pasa1 19.

20) Boedi Harsono, Op. Cit., hal. 302.

21) Peneliti, Wawancara, dengan Belinda Tanto, Notaris dan PPAT Kota Cilegon, (Cilegon: Kantor Notaris dan PPAT Belinda Tanto, S.H., M.kn. Jalan Jendral Ahmad Yani Nomor 48, Kota Cilegon Provinsi Banten, 16 Mei 2019). 
d. tanah tersebut masih sesuai dengan Rencana Tata Ruang Wilayah yang bersangkutan."

Dengan demikian, bidang tanah tersebut sulit untuk mendapatkan perpanjangan jangka waktunya, sehingga bidang tanah tersebut tidak dapat secara efektif digunakan, dikelola, dan dimanfaatkan untuk kesejahteraan pemegang hak atas tanah, masyarakat maupun negara. Selain itu, dampak lain yang dapat timbul dari adanya penelantaran tanah adalah terhambatnya pembangunan nasional. ${ }^{22)}$

Seperti yang sudah dijelaskan bahwa bahwa dalam kaitannya dengan fungsi sosial atas tanah, apabila dalam mempergunakan atau memanfaatkan suatu bidang tanah terdapat pertentangan antara kepentingan perseorangan dan kepentingan umum, maka kepentingan umum yang didahulukan. Dalam hal ini Rencana Tata Ruang Kota Palu sudah berubah sehingga PT Sinar Waluyo selaku pemegang hak atas tanah sawajarnya lebih mendahulukan kepentingan Pemerintah Kota Palu yang dalam hal ini merupakan kepentingan umum karena pada hakikatnya fungsi sosial ini menunjukkan bahwa adanya suatu pembatasan hak atas tanah yang artinya hak atas tanah tidaklah dapat dibenarkan jika semata-mata hanya untuk kepentingan pribadi, apalagi jika hal tersebut merugikan kepentingan masyarakat banyak.

Penertiban dan pendayagunaan tanah terlantar di Kota Palu, dapat memberikan andil besar bukan hanya terhadap nilai pendapatan daerah Kota Palu dan Provinsi Sulawesi Tengah pada umumnya, tetapi juga dengan penguasaan kekayaan alam oleh Negara yang dipergunakan untuk sebesar-besarnya untuk kemakmuran rakyat. ${ }^{23)}$

22) Peneliti, Wawancara, dengan Yunidar, Kepala Sub. Seksi Pengendalian Pertanahan, (Jakarta: Kantor BPN Jakrta Barat, Komplek Permata Buana, Jl. Kembangan Raya, RT.1/RW.3, Kembangan Utara, Kembangan, RT.1/RW.3, Kembangan Utara, Kec. Kembangan, Kota Jakarta Barat, Daerah Khusus Ibukota Jakarta, 17 Mei 2019).

23) Haerani. Husainy dan Diah Astri Ellisa."Tinjauan Yuridis Terhadap Tanah Terlantar Menurut Peraturan Pemerintah Nomor 11 Tahun 2010 Tentang Penertiban Dan Pendayagunaan Tanah Terlantar”. Maleo Jurnal Law. Volume 1 Nomor 2 Januari 2017, hal. 283. 
Fungsi sosial atas tanah mempunyai tujuan agar penggunaan tanah dapat disesuaikan dengan keadaan dan sifat daripada haknya sehingga bermanfaat bagi pemegang hak atas tanah, masyarakat dan Negara serta tercapainya kemakmuran, keadilan dan kebahagiaan bagi rakyat seluruhnya. Namun dalam hal ini tidak berarti kepentingan perseorangan tersingkirkan dan terdesak sama sekali oleh kepentingan umum karena pada dasamya UUPA tetap memperhatikan kepentingan-kepentingan perseorangan karena kepentingan perseorangan dan kepentingan urnum haruslah saling selaras dan mengimbangi satu sama lain.

Dengan demikian fungsi sosial ini menunjukkan adanya suatu pembatasan terhadap tanah yang telah dihaki seseorang bukan hanya berfungsi bagi si empunya saja tetapi juga bagi Bangsa. Indonesia seluruhnya. Terdapat berbagai alasan yang mendasari pemegang hak atas tanah tidak memanfaatkan tanah yang dimilikinya, salah satunya ialah pengalihan bentuk aset kekayaan atau investasi. Hal ini sering kali ditemukan bahwa pemegang hak atas tanah melihat peluang bahwa harga tanah semakin hari semakin tinggi, ditambah apabila tanah tersebut terletak di lokasi yang strategis, sehingga ada beberapa pihak yang memanfaatkan tanah sebagai investasi jangka panjang. Suatu bidang tanah dikuasai ataupun dibeli, lalu dibiarkan tidak diurusi atau ditelantarkan karena dengan berjalannya waktu, maka tanah tersebut harganya akan semakin meningkat. Harga tanah yang semakin meningkat ini disebabkan karena dinamika pembangunan serta semakin banyaknya kebutuhan manusia yang mengakibatkan permintaan akan lahan kian meningkat. Sedangkan dilain pihak, persediaan akan tanah sangat terbatas. ${ }^{24)}$ Pengalihan bentuk investasi pada tanah inii bukan merupakan tindakan yang salah, karena pada hakikatnya menjual kembali tanah yang dimiliki kepada pihak lain merupakan hak pemegang hak atas tanah. Akan tetapi dengan berjalannya waktu dirasa sangat disayangkan karena pihak-pihak yang memilih investasi ini

${ }^{24)}$ I Wayan Suandra, Op., Cit. hal. 46. 
melupakan atau mengabaikan tanggung jawab mereka sebagai pemegang hak dengan melakukan penelantaran tanah terhadap tanah tersebut selama bertahuntahun.

Dengan menggunakan tanah sesuai dengan rencana yang telah ditetapkan pemerintah maka fungsi sosial atas tanah tersebut dapat terpenuhi. PT Sinar Waluyo dalam hal ini tidak menggunakan tanah HGB 01249/ Tondo sesuai peruntukkannya yaitu untuk pembangunan perumahan. Dengan demikian fungsi sosial dari tanah HGB 01249/ Tondo tidak terpenuhi.

Dengan alasan tersebut diatas, langkah BPN dalam menerbitkan Keputusan Kepala Badan Pertanahan Nasional Republik Indonesia No: 14/PTT-HGB/BPN RI/2014 tentang penetapan tanah terlantar HGB 01249/ Tondo atas nama PT Sinar Waluyo merupakan langkah tepat dalam penerapan fungsi sosial atas tanah agar tanah tersebut dapat digunakan, dimanfaatkan dan diusahakan secara optimal sesuai revisi Rencana Tata Ruang Wilayah Kota Palu yaitu sebagai area perkantoran Pemerintah Kota Palu. Akan tetapi dengan adanya pembatalan keputusan penetapan penelantaran tanah tersebut oleh Putusan Pengadilan Tata Usaha Jakarta No: 275/ G/2014/ PTUN-JKT, maka tujuan dari fungsi sosial atas tanah yaitu agar tanah tersebut dapat berguna bagi pemegang hak atas tanah itu sendiri, masyarakat, negara serta memberikan kemakmuran, keadilan dan kebahagiaan rakyat seluruhnya, tidak tercapai.

\section{Penutup}

\section{A. Kesimpulan}

Dalam hal ini, PT Sinar Waluyo sebagai pemegang hak atas tanah selama lebih dari 19 tahun telah tidak mengusahakan, menggunakan, memanfaatkan tanahnya sesuai dengan keadaan atau sifat dan tujuan pemberian hak atau dasar penguasaannya yaitu untuk pengembangan perumahan. BPN RI 
menetapkan tanah HGB 01249/ Tondo atas nama PT Sinar Waluyo sebagai tanah terlantar dengan menerbitkan Keputusan Badan Pertanahan Nasional Republik Indonesia No. 14 /PTT-HGB/BPN RI/ 2014. Hal ini merupakan perwujudan dari asas fungsi sosial atas tanah yang tercantum dalam Pasa1 6 UUPA yang berbunyi bahwa semua hak atas tanah mempunyai fungsi sosial. Hal ini terkait dengan 2 makna fungsi sosial atas tanah yaitu :

1. Pemegang hak atas tanah wajib menggunakan tanahnya sesuai dengan keadaan atau sifat dan tujuan pemberian hak atau dasar penguasannya.

2. Jika dalam mempergunakan atau memanfaatkan suatu bidang tanah terdapat pertentangan antara kepentingan perseorangan dan kepentingan umum maka kepentingan umum yang didahulukan.

Dalam hal ini PT Sinar Waluyo telah menelantarkan tanahnya selama lebih dari 19 tahun dari pertama kali tahanah HGB 01249/ Tondo diperoleh yaitu tahun 1989 sampai dengan tahun 2008 saat PT Sinar Waluyo memperoleh izin lokasi. Pemanfaatan dari tanah HGB 01249/ Tondo ini terhambat karena adanya revisi Rencana Tata Ruang Wilayah Kota Palu dimana tanah HGB 01249/ Tondo termasuk area yang akan dibangun perkantoran milik Pemerintah Kota Palu yang menyebabkan permohonan izin untuk mendirikan bangunan pada tahah HGB 01249/ Tondo ditolak. Setelah itu, PT Sinar Waluyo kembali tidak mengusahakan tanahnya yang mengakibatkan tanah HGB 01249/Tondo teridentifkasi sebagai tanah terlantar. Kantor Wilayah BPN Sulawesi Tengah kemudian memberi tiga kali peringatan tetapi PT Sinar Waluyo tetap tidak mengusahakan tanah HGB 01249/ Tondo. Hal ini mengakibatkan fungsi sosial atas tanah HGB 01249/ Tondo tidak terpenuhi karena PT Sinar Waluyo melakukan pembiaran terhadap tanah HGB 01249/ Tondo tersebut. Dalam hal ini, BPN juga wajib 
berpedoman pada PP 11/2010 dalam menertibkan tanah terlantar agar penertiban ini dapat berjalan efektif dan efisien.

Dengan demikian langkah BPN dalam menerbitkan Keputusan Kepala Badan Pertanahan Nasional Republik Indonesia No: 14/PTT-HGB/BPN RI/2014 yang menetapkan hapusnya hak, memutuskan hubungan hukum, dan tanah HGB Nomor 01249/ Tondo dikuasai langsung oleh negara, mrupakan langkah tepat dalam penerapan fungsi sosial atas tanah agar tanah tersebut dapat digunakan, dimanfaatkan dan diusahakan secara optimal sesuai revisi Rencana Tata Ruang Wilayah Kota Palu yaitu sebagai area perkantoran Pemerintah Kota Palu. Akan tetapi dengan adanya pembatalan Keputusan Kepala Badan Pertanahan Nasional Republik Indonesia No: 14/PTT-HGB/BPN RI/2014 oleh Putusan PTUN No: 275/G/2014/PTUNJKT, maka tujuan dari fungsi sosial atas tanah yaitu agar tanah tersebut dapat berguna bagi pemegang hak atas tanah itu sendiri, masyarakat, negara serta memberikan kemakmuran, keadilan dan kebahagiaan rakyat Indonesia seluruhnya, tidak tercapai.

\section{B. Saran}

Berdasarkan uraian yang telah dijelaskan, maka penulis memberi beberapa saran, yaitu:

1. Bagi pemegang hak atas tanah agar mengusahakan, menggunakan, memanfatkan tanahnya sesuai dengan keadaan atau sifat maupun tujuan pemberian hak atau dasar penguasaannya, juga memenuhi kewajiban-kewajibannya sebagai pemegang hak atas tanah.

2. Bagi Badan Pertanahan Nasional agar dapat melakukan penertiban dan pendayagunaan tanah terlantar dengan lebih teliti, cermat, berhati-hati, efektif serta efisien sesuai dengan peraturan yang berlaku dengan tetap 
memperhatikan kepentingan pemegang hak atas, kepentingan umum serta kepentingan Negara sehingga dapat tercapainya kemakmuran, keadilan dan kebahagiaan rakyat seluruhnya.

3. Bagi Hakim Pengadilan Tata Usaha Negara agar dapat memutus perkara mengenai tanah terlantar secara cermat, adil dan bijak. Sehingga keputusan yang akan dijatuhkan dapat didasari oleh rasa tanggung jawab, keadilan, kebijaksanaan, profesionalisme dan bersifat obyektif.

\section{DAFTAR PUSTAKA}

\section{A. Buku}

Harsono, Boedi. Hukum Agraria Indonesia, Sejarah Pembentukan UndangUndang Pokok Agraria, Asas dan Pelaksanaannya, Cetakan ke-2. (Jakarta: Universitas Tri Sakti, 2015).

Marzuki, Peter Mahmud. Penelitian Hukum. Jakarta: Kencana Prenada Media Group, 2016.

Prayogo, Soesilo. Kamus Hukum Internasional \& Indonesia, Cetakan ke-1. (Jakarta: Wipress, 2007).

Shanan. Penelitian Hukum. Hukum Agraria Indonesia. Jakarta: Setara Press, 2016.

Soemardjono, Maria.S.W. Kebijakan Pertanahan antara Regulasi dan Implementasi, Cetakan ke-3. (Jakarta: Kompas, 2005).

Supriadi. Hukum Agraria, Cetakan ke-4. (Jakarta: Sinar Grafika, 2010).

Tan, Anton. The Real Secret of Succesful Investor and Developer. (Jakarta: PT. Elex Media Komputindo, 2014).

Urip Santoso, Hukum Agraria dan Hak-Hak atas Tanah, Cetakan ke-5, (Surabaya: Kencana Prenada Media Group, 2009).

\section{B. Jurnal}

Haerani. Husainy dan Diah Astri Ellisa. "Tinjauan Yuridis Terhadap Tanah Terlantar Menurut Peraturan Pemerintah Nomor 11 Tahun 2010 Tentang Penertiban Dan Pendayagunaan Tanah Terlantar". Maleo Jurnal Law. Volume 1 Nomor 2 Januari 2017. 
Poluan, Evert M. N. "Kewenangan Pemerintah Daerah Dalam Penanganan Tanah Terlantar di Kabupaten Minahasa". Lex Administratu. Volume 3 Nomor 5 Juli 2015.

Yuwono. "Tanah Terlantar Menyalahi Fungsi Sosial". Jurnal Sosial Humaniora. Volume 2 Nomor 1 Juni 2009.

\section{Perundang-undangan}

Indonesia, Undang-Undang Dasar Negara Republik Indonesia Tahun 1945. Cetakan ke-5. (Jakarta: Kepaniteraan dan Sekretariat Jenderal Mahkamah Konstitusi RI. 2016).

. Undang-Undang Nomor 5 Tahun 1960 tentang Peraturan Dasar Pokok-Pokok Agraria. (Lembaran Negara Republik Indonesia Tahun 1960 Nomor 104, Tambahan Lembaran Negara Republik Indonesia Nomor 2043).

. Peraturan Pemerintah Nomor 40 Tahun 1996 tentang Hak Guna Usaha, Hak Guna Bangunan, Hak Pakai. (Lembaran Negara Republik Indonesia Tahun 1996 Nomor 58, Tambahan Lembaran Negara Republik Indonesia Nomor 3643)

. Peraturan Pemerintah Nomor 36 Tahun 1998 tentang Penertiban dan Pendayagunaan Tanah Terlantar. (Lembaran Negara Republik Indonesia Tahun 1996 Nomor 46, Tambahan Lembaran Negara Republik Indonesia Nomor 3632)

. Peraturan Pemerintah Nomor 11 Tahun 2010 tentang Penertiban dan Pendayagunaan Tanah Terlantar. (Lembaran Negara Republik Indonesia Tahun 2010 Nomor 16, Tambahan Lembaran Negara Republik Indonesia Nomor 5098).

- Peraturan Presiden Republik Indonesia Nomor 20 Tahun 2015 tentang Badan Pertanahan Nasional (Lembaran Negara Republik Indonesia Tahun 2015 Nomor 21). 
. Peraturan Kepala Badan Pertanahan Nasional Republik Indonesia Nomor 4 Tahun 2010 tentang Tata Cara Penertiban Tanah Terlantar.

. Peraturan Kepala Badan Pertanahan Nasional Republik Indonesia Nomor 9 Tahun 2011 tentang Perubahan atas Peraturan Kepala Badan Pertanahan Nasional Republik Indonesia Nomor 4 tahun 2010 tentang Tata Cara Penertiban Tanah Terlantar.

\section{Putusan Pengadilan}

Indonesia. Keputusan Kepala Badan Pertanahan Nasional Republik Indonesia No: 14 /PTT-HGB/ BPN RI/ 2014.

Penetapan Pengadilan Tata Usaha Negara Jakarta No: 275/ G/2014/ PTUN-JKT. 